\title{
Managers' Perspectives about the Relationship between Tourism and Climate Change: Case of the Republic of Croatia
}

\author{
Aleksandar Racz \\ University of Applied Health Sciences, Zagreb, Croatia \\ aleksandar.racz@zvu.hr \\ Dora Smolčić Jurdana \\ University of Rijeka, Faculty of Tourism and Hospitality Management, Croatia \\ doras@fthm.hr \\ Zvonimira Šverko Grdić \\ University of Rijeka, Faculty of Tourism and Hospitality Management, Croatia \\ zgrdic@fthm.hr
}

\begin{abstract}
Assuming a two-way relationship between climate change and tourism, it is very important to know the beliefs and attitudes of tourist managers. Research of beliefs and attitudes of tourist managers is a key problem of this research. Beliefs and attitudes of tourist managers are affected by different factors such as: sociodemographic characteristics, especially gender; level of education; length of service in the tourism sector; membership in ecological NGOs; and beliefs and attitudes about climate change. To investigate managers' opinions, the authors created a survey which focused on all managers who manage categorized facilities by type in the Republic of Croatia. The results have shown significant differences in the beliefs and attitudes about the interinfluence of climate change and tourist accommodation. Managers who are female, who have completed tertiary education, who are members of ecological NGOs and who consider themselves activists, and those who have more years of work experience, showed stronger pro-environmental attitudes and higher levels of ecological awareness.
\end{abstract}

Keywords: attitudes, beliefs, climate change, management, tourism, destinations

(cc)BY-SA https://doi.org/10.26493/2335-4194.14.53-70

\section{Introduction}

Climate change has become the biggest challenge and threat to the survival of human civilization, with many consequences for virtually every aspect of human life. There is a two-way relationship between tourism and climate change as tourism is largely dependent on the climate and is influenced by climate change in real time (Mahadew \& Appadoo, 2019).

It is estimated that tourism is the source of at least
$8 \%$ of global $\mathrm{CO}_{2}$ emissions which is why great efforts are being made on the global and national levels to mitigate the consequences of climate change (Wajahat et al., 2020). This also involves planning and taking measures to prevent further negative consequences that might become irreversible in the future (Kocak et al., 2020; Becken et al., 2020). Many authors agree that climate change originates in nature, 'but has causes in an economic, cultural and political system 
that is spreading around the world' (Ančić et al., 2016).

On the theoretical level this research has started from basic principles derived from the Theory of Planned Behaviour (т Р в) that looks at intentions to behave,' and not necessarily actual actions of individuals. It argues that attitudes, subjective norms and perceived behavioural control affect intentions to act and these in turn predict behaviour. т Р в starts from the premise that individuals make logical, reasoned decisions to engage in specific behaviour by evaluating the information available to them. The performance of a behaviour is determined by the individual's intention to engage in it (influenced by the value the individual places on the behaviour, the ease with which it can be performed and the views of significant others) and the perception that the behaviour is within his/her control (Ajzen, 1985). The theory was intended to explain all behaviour over which people have the ability to exert self-control. The key component to this model is behavioural intent; behavioural intentions are influenced by the attitude concerning the likelihood that the behaviour will have the expected outcome and the subjective evaluation of the risks and benefits of that outcome. Rosenberg's three-component structure was discussed when developing the research plan, in the sense that an attitude is a whole made up of cognitive (what an individual thinks of an object of attitude), emotional or affective (what an individual feels about an object of attitude) and conative or behavioural components (how an individual intends to behave towards an object of attitude) (Alessandri \& Vecchione, 2015). This model of attitude structure is also called the ABC model (affect, intention of behaviour, cognition) (Stern \& Oskamp, 1987).

The theoretical concept on which this research of beliefs and attitudes leans is the theory of the MODE model developed by Fazio (1993) and Myers and Twenge (2016). The model broadens the one-dimensional approach to attitudes by emphasizing the undisputable connection between beliefs, attitudes and intention of behaviours, with Myers and Twenge aware that 'the relationship of individual components of attitude is not simple and unambiguous' (Ajduković et al., 2005).

The MODE model ('motivation and opportunities as determinants') assumes that attitudes can influence intention of behaviour either through the conscious implications that they have on the intention of behaviour or by automatic selective processing for the posture of significant information. Specifically, a more precise MODE model is based on the assumption that attitudes, in addition to referring to certain objects, have their 'strength,' and that we can locate it on the so-called 'strength scale' accordingly, where zero is the complete indifference to the object of attitude. Only strong attitudes are stable and reliable in predicting behaviour. Attitudes also represent a link between the object of attitude itself and the individual's evaluation of the object. Attitudes are based on experience that in this case forms the basis of the evaluation. In the MODE model, the authors emphasize the importance of the so-called concept of activation of the aforementioned object connection and the existing evaluation, and link it to the scale of power where relative indifference is found at the lower part of the strength scale. In order for the attitude-behaviour process to be activated, there must be an external influence that can also represent a simple question posed about the object itself. At the opposite end of the scale where attitudes are strong, this activation can occur and automatically, without external stimuli, is already sufficient perception of the object to initiate the attitude-intention of the behaviour process.

Authors Sinatra et al. (2012) measured attitudes toward climate change caused by anthropological activity and found that respondents who had a more accepting attitude toward climate change were more likely to express a willingness to act. Authors Garay et al. (2018) explored cognitive mechanisms that motivate managers to introduce sustainability practices in their businesses. They concluded that managers' subjective norms explained more of their behavioural intentions than their attitudes or perceived behavioural controls.

The starting point for this paper was the assumption of a two-way relationship between climate change and tourism, and the importance of knowing the beliefs and attitudes of multiple stakeholders - managers in the entire tourist accommodation industry as key persons in tourism management and decisionmaking, and key actors in implementing environmen- 
tal protection, as well as implementing and developing business policies in the area of sustainable development (Bohdanowicz, 2005). The main objective of this paper was to analyse the influence of four different sociodemographic characteristics among managers concerning beliefs and attitudes on climate change: gender, level of education, length of service in the tourism sector and membership in ecological NGOS or activism in ecological actions and initiatives (Racz, 2019). The researchers' intention was to provide a series of insights that might be relevant for the development of sustainable practices in the tourism sector, and particularly the hotel industry in general, as they contribute to understanding the attitudes of key decision-makers. This can also provide the basis for predicting their intention of behaviour in relation to the application of environmental protection measures.

\section{Literature Review}

Climate change poses a unique challenge to the entire human civilization and affects all aspects of human life, including tourism. The Earth is currently $0.7^{\circ} \mathrm{C}$ warmer than in 1900 , and if all emissions are stopped today, the Earth will warm by a further 0.5$1^{\circ} \mathrm{C}$ in the next decade. Research shows that the biggest impact on these changes is the release of carbon dioxide into the atmosphere, which due to its properties enhances the greenhouse effect on Earth. Interest in climate change has increased in recent years, especially after the 2009 United Nations Climate Change Conference held in Copenhagen (Scott \& Becken, 2010; Gössling et al., 2012; Rosselló-Nadal, 2014; Rutty et al., 2017). Dogru et al. (2019) explore the extent to which vulnerability and resilience to climate change affect tourism and the overall economy. The results indicate that tourism is both more vulnerable and more resilient to climate change compared to the economy in general. Scott et al. (2019) argue that vulnerability is highest in many countries where tourism represents the largest percentage of GDP, as well as regions where tourism growth is expected to be the strongest over the coming decades.

Tourism depends on having a favourable climate, preserved environment and rich flora and fauna (Buckley, 2011; Müller \& Weber, 2008). To a degree, climate elements such as temperature, total hours of sunshine and rain periods define international tourism flows in Europe (Joop et al., 2015). Numerous key tourism factors are affected by climate change (Scott \& Lemieux, 2010; Kozak et al., 2008; Hamilton \& Tol, 2007).

Rising sea levels, changing ecosystems, changes in the water system on Earth, various health effects and more frequent extreme weather events will affect tourism not only in terms of reducing comfort, but also in terms of reduced safety (Michailidou et al., 2016). Tourism is extremely sensitive to climate change and it can endure many negative or positive effects (Joop et al., 2013; Wong et al., 2013; Schliephack \& Dickinson, 2017).

The tourism sector has seen significant growth in the last four decades (Gössling et al., 2013) and it is also a significant factor in the economic development of both developed and developing countries (Cannonier \& Burke, 2018; Dogru \& Bulut, 2018: Becken, 2019; Hall, 2019; Jentos et al., 2012; Saarinen \& Rogerson, 2014; Scheyvens \& Hughes, 2018). Some authors have focused on exploring the impact of climate change on tourism demand based on IPCC (Intergovernmental Panel on Climate Change) climate change projections (Hindley \& Font, 2017; Hall et al., 2016; Amelung et al., 2007; Scott \& Brenda, 2007). These projections encompass the global level, the country level, and destinations such as coastal areas and islands, as well as skiing destinations (Wyss \& Abegg, 2014; Dawson \& Scott, 2007).

There are not, however, many studies focused on the beliefs and attitudes of managers in tourism concerning the impact of climate change, especially when it comes to the interdependence between climate change and accommodation in tourism. Research focused on manager beliefs and attitudes regarding climate change and tourism, or research of a single aspect, is typically conducted for a particular country or destination. Trawoger (2014) analysed climate change perceptions of winter tourism stakeholders in Tyrol (Austria). He concluded that growing awareness of climate change is limited to perceiving the issue as a global phenomenon. Hall et al. (2016) presented a systematic overview of tourism accommodation providers and consumer attitudes, intention of behaviour and prac- 
tices pertaining to sustainable development, sustainability in general and climate change. Legrand et al. (2012) hypothesized that the hotel industry is responsible for $\mathrm{CO}_{2}$ emissions into the atmosphere and thus responsible for the intensifying climate change. They concluded that hotels have recognized how important sustainability and its principles have become and that green investments are on the rise. Yu-Ping, Hall \& Ozzane (2012) proposed that hotels and the hotel industry are the most vulnerable to climate change as a consequence of their primary resources. Their research results encompass attitudes, awareness and intention of behaviour of Taiwanese hotel managers with regard to climate change, its potential impact and their ecological practices in general. Authors Dube and Nhamo (2020) used a method approach; their study sought to document tourist perceptions and attitudes regarding the impact and future of the Victoria Falls World Heritage Site. Authors Torres-Bagur et al. (2019) conducted interviews with owners and managers to understand perceptions and identify the main problems associated with climate change in order to design effective mitigation and adaptation strategies to guarantee the sustainability of tourism and natural resources.

Tourism needs to introduce certain adjustment measures to boost the positive and mitigate the negative effects of future climate change (Perić \& Šverko Grdić, 2017). However, it must be emphasized that climate change will have a different effect on different destinations and, consequently, on the economic benefits of tourism.

\section{Mitigating Tourism-Induced Climate Change}

There are two primary strategic approaches when it comes to climate change - mitigation and adaptation. The two should not be observed separately, they are not an either/or choice. Instead, they are connected, alternative strategies that can achieve the best results through the use of well-developed instruments and measures for the simultaneous implementation of both. The goal of mitigation is to slow down climate change, while adaptation involves lowering climate change vulnerability (Jopp et al., 2015).

Another aim of the mitigation strategy is to reduce harmful emissions into the atmosphere, thus reducing the greenhouse effect. Mitigation strategies in general include enhancing, restoring, creating, or preserving current standards in order to offset unavoidable effects (Dogru et al., 2019). Climate resilience and the need for decarbonization are highlighted in communication in the tourism sector, but there is little evidence of significant action being taken regarding mitigation (Gössling \& Scott, 2018). All economic sectors will be required to contribute to reducing emissions in order to achieve the objective set by the Paris Climate Agreement - to limit global warming to $2^{\circ} \mathrm{C}$ above pre-industrial levels. Any increase in emissions from specific sectors or countries will mean that there is a widening gap between trajectories and mitigation objectives. For tourism, in a business-as-usual scenario, this would correspond to more than $2.5 \mathrm{Gt}$ of $\mathrm{CO}_{2}$ per year by 2050 (European Travel Commission, 2018).

Adaptation and mitigation are very important strategies for responding to climate change and they are equally important (Hambira \& Saarinen, 2015). Without early and timely mitigation, the costs of adaptation will rise, and the ability of countries and individuals to adapt effectively will be constrained. Understanding the nature and consequences of climate change is the basis of any serious mitigation or adaptation policies (Galeotti \& Roson, 2012). In order to be able to implement mitigation and adaptation, it is important to assess what the cost of inaction would be, i.e. the economic impact of climate change in a baseline scenario in which no policies are implemented. The greening of accommodation establishments (Hoogendoorn et al., 2015) and attempts at creating carbon-neutral tourism destinations could potentially be viable and address both adaptation and mitigation strategies.

\section{Methodology}

The study included managers from 1,084 individual tourist accommodation establishments from the territory of the entire Republic of Croatia, included in the list of categorized objects on the Ministry of Tourism's website on March 7, 2019. The survey included categorized hotels and apart-hotels, hotel and apartment complexes, categorized campsites, and marinas. It was conducted using online surveys and was completely anonymous, with targeted distribution of survey ques- 
tionnaires, i.e. calls through professional associations and competent bodies and chambers in the period from April to June 2019. To determine beliefs and attitudes about climate change and the impact of climate change and tourist accommodation, a questionnaire prepared for this research was used, which was based on the Euro Barometer Questionnaire 300 and 459 (European Commission, 2009, 2017). Furthermore, the questionnaire included a selection of modified questions used in previous research, but targeted with regard to the target population - top managers in tourist accommodation facilities in Croatia (Bohdanowicz, 2005, 2006; Leiserowitz et al., 2018). The final form of the survey questionnaire was obtained by including a series of original questions aimed precisely at the goals of this research and the target population, thus creating an original questionnaire.

Attitudes and beliefs were explored using the attitude measurement scale. The expressed degree of agreement with the proposed claims and the standardized manner of assessment determined the respondent's position. The first part of the questionnaire used a series of 30 statements related to global warming and climate change, and the relationship between tourism and climate change, according to which respondents had to express their degree of agreement with each statement on a 7-point Likert scale, with grade 1 meaning 'strongly disagree', 4 meaning 'neither agree nor disagree' and 7 meaning 'strongly agree' with the statement. The scale examined the cognitive, intention of behaviour and affective components of attitude. In the second part of the questionnaire, respondents were offered 6 terms related to the parent term 'climate change and global warming, in which they were asked to indicate the position best matching their feelings about climate change and global warming on a 7-point scale, which additionally examined the affective component of attitude. The action component of attitude was examined through a series of 8 statements, each related to individual personal involvement or intent to participate in any of the aforementioned adaptation measures or measures for reducing the negative impact of global warming through personal actions, expressed on a 7-point scale.

Post hoc comparisons of $p$-values were performed in each of the three component domains (cognitive, affective, and conative) for each of the observed sociodemographic characteristics. In order to analyse the share and contribution of each component of the attitude to the overall expressed level of environmental awareness, some total factor scores (given the different number of questions involved) were converted to a scale from o (least agreement/no agreement with each factor) to 100 (complete agreement with a factor) according to the formula in which the numerator is formed by the difference of the scores of the ladder of each factor, reduced by the smallest possible amount of the ladder of the factor, the denominator represents the possible range of the ladder of factors, and the result is multiplied by one hundred. Orientation to the right (higher score) denotes ecologically friendly intention of behaviour or understanding of the pattern, consequences, and correlation of phenomena with global warming and climate change.

IB M SPss Statistics software version 25.0 was used in the analysis. Data processing was performed using Microsoft Excel. In the entire survey the KolmogorovSmirnov test was used to analyse the distribution of continuous numerical values, and corresponding nonparametric tests were applied according to the obtained data. Categorical and nominal values were presented using corresponding frequencies and shares. Continuous values were presented using medians and interquartile ranges, and the differences between them were analysed by the Kruskal-Wallis test, and presented in a box and whisker plot showing median values, interquartile ranges, minimum and maximum values, and extreme values which differ from the medians by more than 1.5 interquartile ranges.

\section{Results and Findings}

From the total of 1,084 categorized tourist accommodation establishments, the survey collected a total of 283 fully completed questionnaires, which represents a response rate of $26.1 \%$. The study included 283 participants of different genders, of which 168 (59.36\%) were male and 115 (40.64\%) were female. Analysing the highest achieved level of education has shown that among the 283 participants there were 77 participants $(27.20 \%)$ with secondary school education, 66 partici- 
Table 1 Descriptive Statistics: Numerical Data for Cognitive Component

\begin{tabular}{|c|c|c|c|c|c|c|c|c|c|c|}
\hline Category & Item & $N$ & sv & SD & Min & Max & Perc. 25 & Median & Perc. 75 & $P$ \\
\hline \multirow[t]{2}{*}{ Gender } & Male & 168 & 60.31 & 19.15 & 19.70 & 90.91 & 42.42 & 65.15 & 76.89 & $<0.001$ \\
\hline & Female & 115 & 73.70 & 12.76 & 32.58 & 95.45 & 67.42 & 76.52 & 81.82 & \\
\hline \multirow[t]{4}{*}{ Educational level } & Secondary & 77 & 47.58 & 14.58 & 22.73 & 81.82 & 35.61 & 46.21 & 57.58 & $<0.001$ \\
\hline & High & 66 & 63.28 & 16.73 & 25.76 & 91.67 & 52.27 & 67.42 & 74.24 & \\
\hline & University & 124 & 77.06 & 8.85 & 43.94 & 95.45 & 73.11 & 79.92 & 82.20 & \\
\hline & Postgraduate & 16 & 75.71 & 17.84 & 19.70 & 90.15 & 66.67 & 79.55 & 88.64 & \\
\hline \multirow[t]{2}{*}{ NGO membership } & No & 244 & 63.30 & 18.13 & 19.70 & 91.67 & 50.38 & 68.18 & 77.65 & $<0.001$ \\
\hline & Yes & 39 & 81.06 & 6.36 & 65.91 & 95.45 & 76.52 & 81.06 & 85.61 & \\
\hline \multirow{3}{*}{$\begin{array}{l}\text { Working experience } \\
\text { in tourism }\end{array}$} & $<5$ years & 65 & 49.57 & 16.29 & 26.52 & 90.15 & 34.85 & 46.97 & 61.36 & $<0.001$ \\
\hline & $5-15$ years & 133 & 68.83 & 17.45 & 22.73 & 91.67 & 58.33 & 74.24 & 81.06 & \\
\hline & $>15$ years & 85 & 73.31 & 11.80 & 19.70 & 95.45 & 65.91 & 75.00 & 81.06 & \\
\hline
\end{tabular}

Table 2 Descriptive Statistics: Numerical Data for Affective Component

\begin{tabular}{|c|c|c|c|c|c|c|c|c|c|c|}
\hline Category & Item & $N$ & sv & SD & Min & Max & Perc. 25 & Median & Perc. 75 & $P$ \\
\hline \multirow[t]{2}{*}{ Gender } & Male & 168 & 48.58 & 21.59 & 8.33 & 86.11 & 27.78 & 52.78 & 66.67 & $<0.001$ \\
\hline & Female & 115 & 61.11 & 15.19 & 13.89 & 83.33 & 55.56 & 63.89 & 72.22 & \\
\hline \multirow[t]{4}{*}{ Educational level } & Secondary & 77 & 34.38 & 18.15 & 8.33 & 86.11 & 19.44 & 27.78 & 50.00 & $<0.001$ \\
\hline & High & 66 & 51.89 & 18.89 & 13.89 & 86.11 & 38.89 & 58.33 & 66.67 & \\
\hline & University & 124 & 66.15 & 11.62 & 27.78 & 83.33 & 61.11 & 69.44 & 75.00 & \\
\hline & Postgraduate & 16 & 57.12 & 10.49 & 30.56 & 66.67 & 55.56 & 61.11 & 62.50 & \\
\hline \multirow[t]{2}{*}{ NGO membership } & No & 244 & 50.94 & 20.16 & 8.33 & 86.11 & 31.94 & 55.56 & 66.67 & $<0.001$ \\
\hline & Yes & 39 & 70.73 & 8.76 & 38.89 & 86.11 & 66.67 & 72.22 & 75.00 & \\
\hline \multirow{3}{*}{$\begin{array}{l}\text { Working experience } \\
\text { in tourism }\end{array}$} & $<5$ years & 65 & 37.39 & 20.66 & 8.33 & 83.33 & 19.44 & 30.56 & 55.56 & $<0.001$ \\
\hline & 5-15 years & 133 & 56.43 & 18.96 & 13.89 & 83.33 & 44.44 & 61.11 & 69.44 & \\
\hline & $>15$ years & 85 & 61.80 & 13.91 & 27.78 & 86.11 & 52.78 & 66.67 & 72.22 & \\
\hline
\end{tabular}

pants (23.32\%) with higher education, 124 participants (43.81\%) with a university degree and 16 (5.67\%) with postgraduate education. Regarding the length of employment or, to put it another way, the length of working experience in tourism, 65 (22.97\%) of respondents have been working in tourism for less than 5 years, 133 (46.99\%) have been working for 5-15 years, and 85 (30.04\%) for more than 15 years.

For the visual presentation of obtained data a boxplot was used as a standardized way of displaying the dataset based on a five-number summary: the minimum, the maximum, the sample median, and the first and third quartiles. A boxplot, is a method for graphically depicting groups of numerical data through their quartiles. For further analysis we added Tables 1-3 that numerically show the elements of descriptive statistics for each individual component of the attitude on the basis of which the graphs were made.

\section{Cognitive Component}

The study found statistically significant differences in the cognitive component of attitude with respect to the gender of managers, with female managers showing statistically significant greater acceptance of the pro- 
Table 3 Descriptive Statistics: Numerical Data for Conative Component

\begin{tabular}{|c|c|c|c|c|c|c|c|c|c|c|}
\hline Category & Item & $N$ & SV & SD & Min & Max & Perc. 25 & Median & Perc. 75 & $P$ \\
\hline \multirow[t]{2}{*}{ Gender } & Male & 168 & 69.95 & 19.47 & $33 \cdot 33$ & 100.00 & 52.08 & 77.08 & 85.42 & $<0.001$ \\
\hline & Female & 115 & 78.79 & $15 \cdot 34$ & $33 \cdot 33$ & 100.00 & 68.75 & 81.25 & 89.58 & \\
\hline \multirow[t]{4}{*}{ Educational level } & Secondary & 77 & 57.87 & 16.20 & $33 \cdot 33$ & 100.00 & 45.83 & 54.17 & 66.67 & $<0.001$ \\
\hline & High & 66 & 71.31 & 16.90 & 35.42 & 93.75 & 62.50 & 77.08 & 83.33 & \\
\hline & University & 124 & 84.26 & 12.90 & $33 \cdot 33$ & 100.00 & 80.21 & 85.42 & 92.71 & \\
\hline & Postgraduate & 16 & 75.13 & 14.04 & 50.00 & 95.83 & 68.75 & 68.75 & 88.54 & \\
\hline \multirow[t]{2}{*}{ NGO membership } & No & 244 & 70.77 & 18.02 & $33 \cdot 33$ & 100.00 & 54.17 & 75.00 & 85.42 & $<0.001$ \\
\hline & Yes & 39 & 90.92 & 8.69 & 70.83 & 100.00 & 85.42 & 91.67 & 100.00 & \\
\hline \multirow{3}{*}{$\begin{array}{l}\text { Working experience } \\
\text { in tourism }\end{array}$} & $<5$ years & 65 & 57.85 & 17.41 & 33.33 & 95.83 & 43.75 & 52.08 & 70.83 & $<0.001$ \\
\hline & 5-15 years & 133 & 74.11 & 16.73 & $33 \cdot 33$ & 100.00 & 60.42 & 77.08 & 85.42 & \\
\hline & $>15$ years & 85 & 84.66 & 12.22 & 37.50 & 100.00 & 79.17 & 87.50 & 93.75 & \\
\hline
\end{tabular}

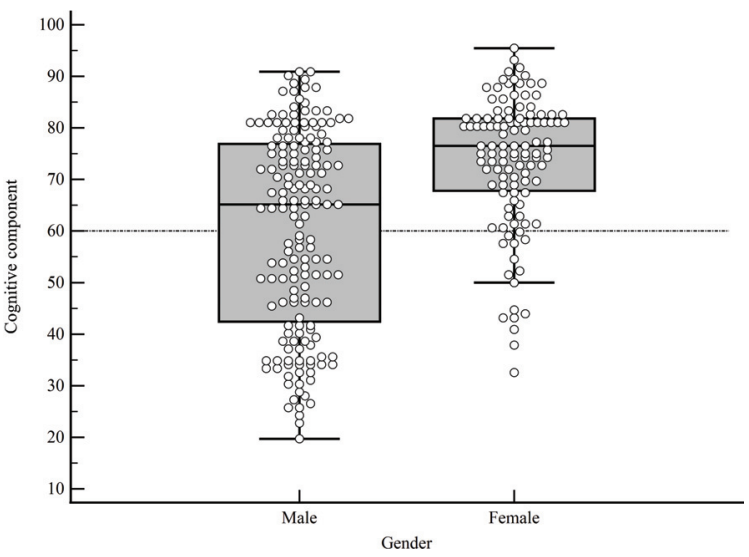

Figure 1 Differences in Respondents' Attitudes Shown in a Box and Whisker Plot with Respect to Respondents' Gender for the Cognitive Component of Attitude

ecological claims offered compared to male managers, or higher levels of environmental awareness (see Figure 1).

The post hoc comparisons showed that there is a statistically significant difference in the attitudes of managers depending on the level of education completed, and in each of the comparisons made between the compared 4 groups, except when comparing the attitudes of managers with a high school diploma compared to those of postgraduate students. From the data presented in Figure 2, it can be concluded that the

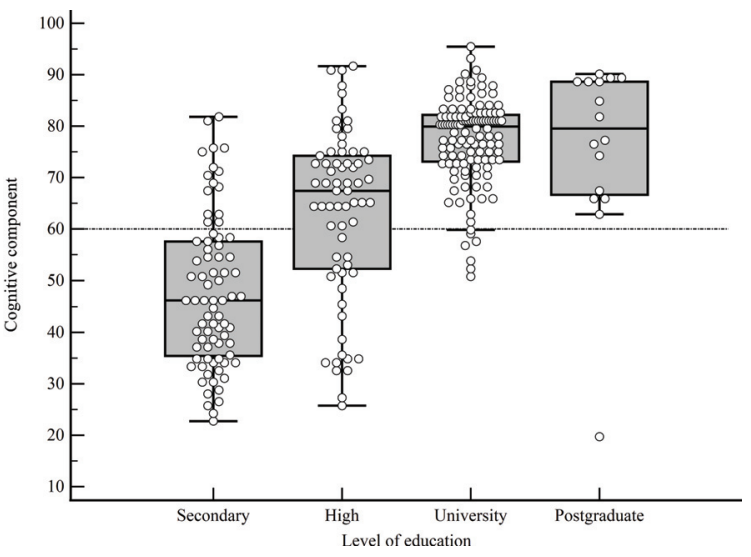

Figure 2 Differences in Respondents' Attitudes Shown in a Box and Whisker Plot with Respect to Respondents' Level of Education for the Cognitive Component of Attitude

highest degree of acceptance of the claims, and thus the highest level of environmental knowledge, was shown by the managers with the highest level of education. The lowest scores were recorded in the group of respondents whose highest level is secondary education, which confirmed the importance of the completed level of previous education in the formation of the cognitive component of attitudes (see Figure 2).

Membership of respondents in non-governmental (NGo) environmental associations was expected to prove to be a statistically significant differentiating 


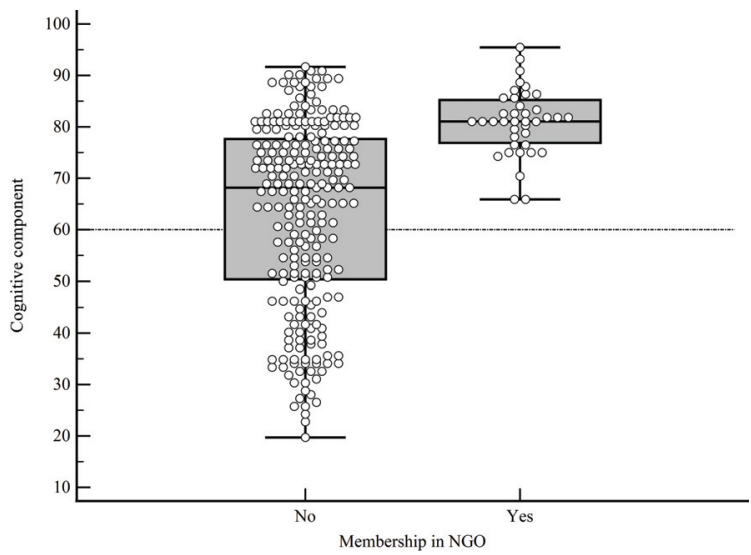

Figure 3 Differences in Respondents' Attitudes Shown in a Box and Whisker Plot with Respect to Respondents' Membership in NGO for the Cognitive Component of Attitude

factor for the cognitive component of managerial attitude. Managers involved in the work of environmental NGOS are expected to express significantly more proecologically affirmative attitudes than socially nonengaged respondents, relative to those who are not active members of the NGO scene (see Figure 3 ).

Work experience has emerged through post hoc comparisons as a factor leading to a statistically significant difference in attitudes when comparing three groups of respondents: those with less than five years of work experience compared with those with 5-15 years of experience or compared with those respondents with over 15 years of experience. Differences were also confirmed when comparing the attitudes of respondents with 5-15 years of experience compared to those of respondents with more than 15 years of experience. The data shows that the group of managers with the most seniority shows, in the cognitive attitude component, the highest degree of acceptance or agreement with the statements offered, compared to the other two groups of respondents, related to the most developed level of environmental awareness (see Figure 4).

\section{Affective Component}

The study found statistically significant differences in the affective, emotional component of attitude with respect to manager gender. Female managers showed a

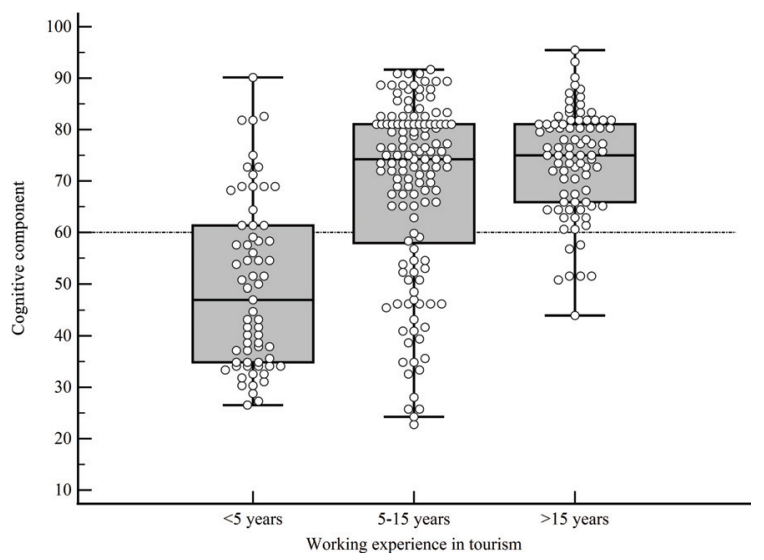

Figure 4 Differences in Respondents' Attitudes Shown in a Box and Whisker Plot with Respect to Respondents' Years of Work Experience in Tourism for the Cognitive Component of Attitude

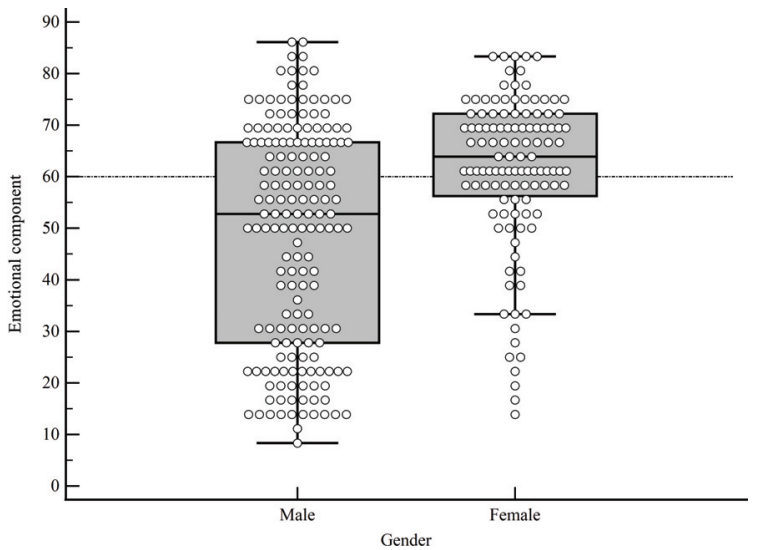

Figure 5 Differences in Respondents' Attitudes Shown in a Box and Whisker Plot with Respect to Respondents' Gender for the Emotional Component of Attitude

statistically significant greater acceptance of the proenvironmental assertions offered than male managers (see Figure 5).

The conducted post hoc comparisons showed that there is a statistically significant difference in the attitudes of managers depending on the level of their highest completed education, and in each of the comparisons conducted between each of the 4 groups.

From the data presented in Figure 6, it can be concluded that the highest degree of acceptance of the 


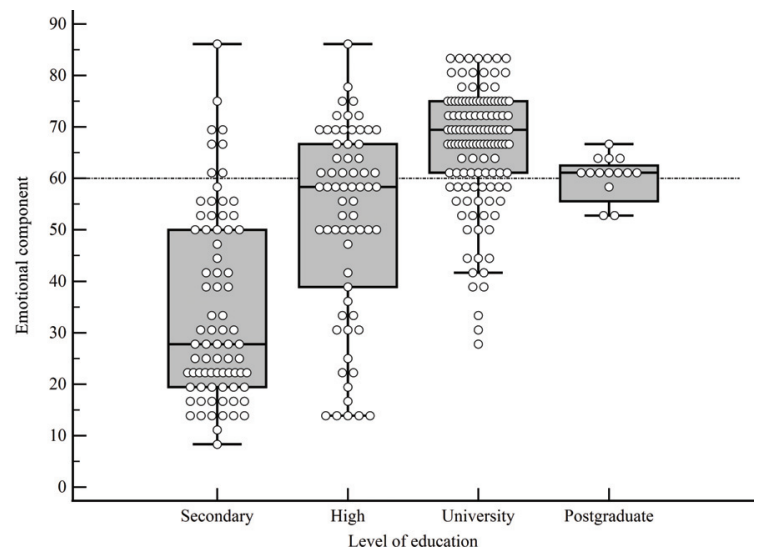

Figure 6 Differences in Respondents' Attitudes Shown in a Box and Whisker plot with Respect to Respondents' Level of Education for the Emotional Component of Attitude

claims, and thus the highest degree of environmental sensitivity in the affective, emotional component, was shown by the managers with the highest completed education, while the lowest results were recorded in the group of respondents with the lowest, i.e. secondary education, thus confirming the importance of the completed level of previous education in the attitude formation process (see Figure 6).

Respondents' membership in NGOs, as expected, proved to be a statistically significant differentiating factor for the affective component of managerial attitude. Managers involved in the work of environmental NGOs are expected to have significantly more proecologically affirmative views than respondents not engaged in the work of environmental NG Os (see Figure 7).

Work experience has emerged through post hoc comparisons as a factor that leads to a statistically significant difference in managerial attitudes when comparing the attitudes of managers classified into three groups: managers with less than five years of service, managers with 5-15 years of service, and those with over 15 years of service.

Differences were also confirmed when comparing the attitudes of respondents with 5-15 years of experience with those of over 15 years of experience. The data shows that the group of managers with the most years of experience shows, in the affective, emotional com-

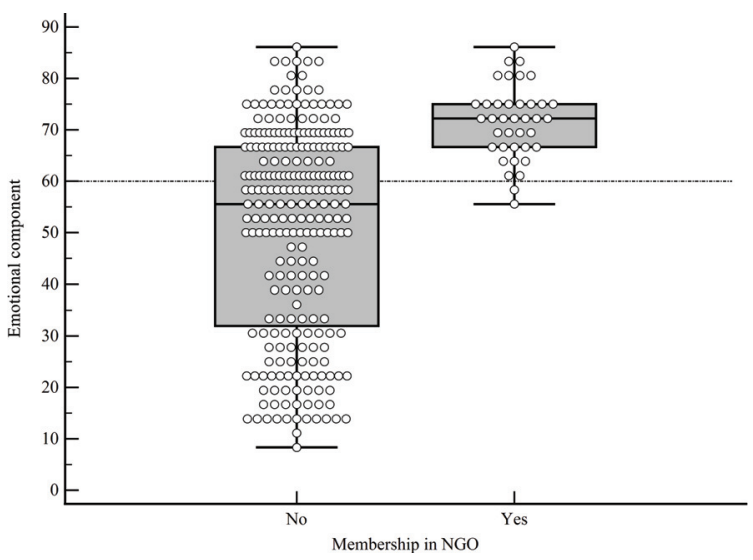

Figure 7 Differences in Respondents' Attitudes Shown in a Box and Whisker Plot with Respect to Respondents' Membership in NGO for the Emotional Component of Attitude

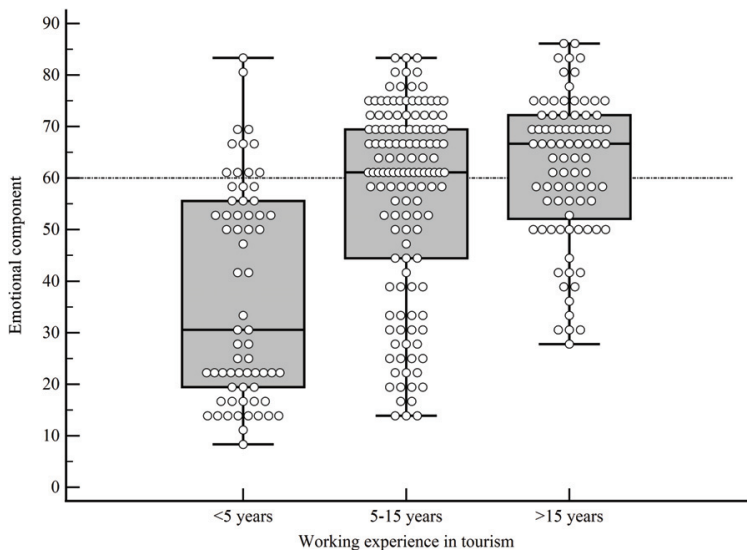

Figure 8 Differences in Respondents' Attitudes Shown in a Box and Whisker Plot with Respect to Respondents' Years of Work Experience in Tourism for the Emotional Component of Attitude

ponent, the highest degree of acceptance or agreement with the statements offered compared to the other two groups of respondents (see Figure 8).

\section{Behavioural, Conative Component}

The study found statistically significant differences in attitudes for the conative, behavioural component of attitude with respect to the gender of managers, graphically presented in Figure 9.

It can be concluded that female managers showed 


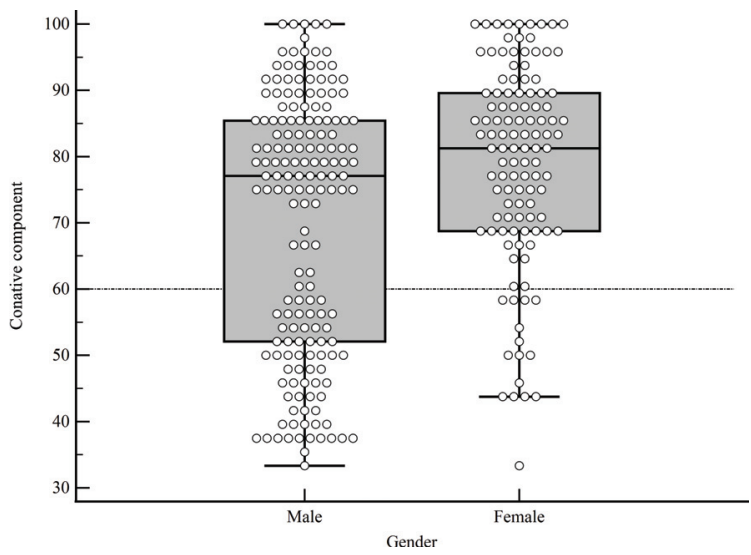

Figure 9 Differences in Respondents' Attitudes Shown in a Box and Whisker Plot with Respect to Respondents' Gender for the Conative Component of Attitude

a statistically significant greater acceptance of the proecological claims offered compared to male managers. This points to the conclusion that women managers are more sensitive to participating in environmental actions and implementing environmental strategies and plans (see Figure 9).

The post hoc comparisons showed that there is a statistically significant difference in attitudes of managers depending on the level of education completed, and in each of the comparisons between the 4 groups, except when comparing the attitudes of managers with completed university education with those with postgraduate education.

From the data presented in Figure 10, it can be concluded that the highest degree of acceptance of the claims, and thus the highest degree of environmental sensitivity in the intention of behaviour component was shown by the managers with the highest qualifications, while the lowest results were recorded in the group with the lowest, i.e. secondary education. In this way, the importance of the completed level of previous education in forming the intention of behaviour component of attitudes was confirmed (see Figure 10).

Respondents' membership in NGOs proved to be a statistically significant differentiating factor for the conative, intention of behaviour component of the managers' attitudes. Managers involved in the work of NGOS are significantly more pro-ecologically active

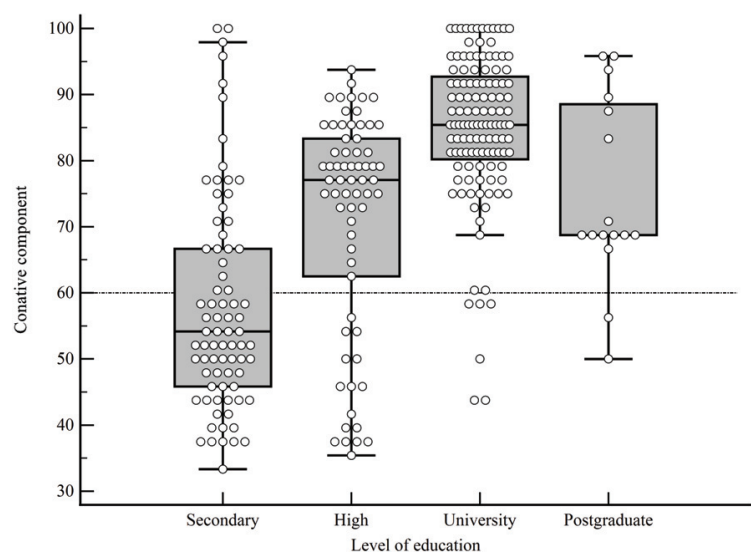

Figure 10 Differences in Respondents' Attitudes Shown in a Box and Whisker Plot with Respect to Respondents' Level of Education for the Conative Component of Attitude

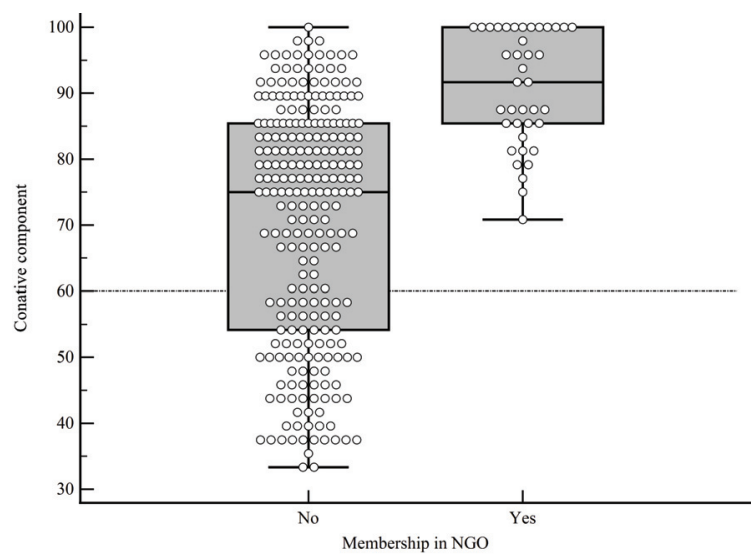

Figure 11 Differences in Respondents' Attitudes Shown in a Box and Whisker Plot with Respect to Respondents' Membership in NGO for the Conative Component of Attitude

in practice, and thus exhibit significantly more proecologically affirmative attitudes than non-engaged respondents.

The results presented in Figure 11 could perhaps be explained by the assumption that there is positive feedback between respondents' engagement in environmental actions organized by NGOS and their proenvironmental intention of behaviour in the tourism business entity in which they hold a managerial position (see Figure 11). 


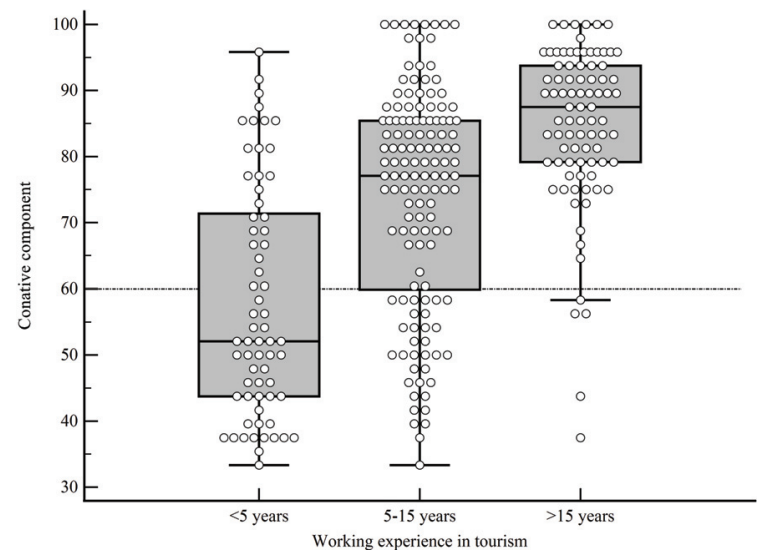

Figure 12 Differences in Respondents' Attitudes Shown in a Box and Whisker Plot with Respect to Respondents' Years of Work Experience in Tourism for the Conative Component of Attitude

Work experience has been shown through post hoc comparisons as a factor that leads to a statistically significant difference in attitudes when comparing three groups of respondents depending on length of service, or when comparing attitudes of those with less than five years of service compared to those with 5-15 years or with views of those with over 15 years of service.

Differences were also confirmed when comparing the attitudes of respondents with 5-15 years of experience compared with those with more than 15 years. The data presented in Figure 12 shows that the group of managers with the most years of experience also shows in the intention of behaviour component the highest degree of acceptance or agreement with the offered statements. This, in practice, means that the highest pro-ecological intention of behaviour can be expected from this group in comparison with the other two groups of respondents (see Figure 12).

\section{Discussion}

Taking into account all other environmental problems, climate change has become the biggest challenge and threat to the survival of the human civilization, with far reaching consequences and a wide influence on and relationship with virtually every aspect of human life. The 2014 International Panel on Climate Change stated that it is confirmed with near certainty that human activities are the dominant cause of global warming, leading to multiple manifestations of climate change' (IPCC, 2014). This paper is focused on the beliefs and attitudes of tourism managers on the interplay between climate change and tourism, because the selection of a sustainable tourism development strategy, and particularly its implementation, is closely linked to the beliefs and attitudes of key decision makers. That is, the views, beliefs and attitudes of top managers, the decision makers, is what the success of the implementation of the selected strategies depends on (Schliephack \& Dickinson, 2017). Attitudes and beliefs are formed in the processes of socializing and are acquired directly, based on experience with the object of the attitude, or indirectly, through interaction with the social environment. At the same time, attitudes, as an acquired tendency to react either positively or negatively to external persons, objects or situations, or to one's own qualities, ideas, or actions, are connected to certain sociodemographic characteristics. This has once again been confirmed by our results. Managers' attitudes and beliefs are essential in planning how to minimize or mitigate the negative impacts of climate change on the tourist accommodation industry, because several authors suggest that unfortunately, no prevention of negative tourism impact is possible, but it is possible to manage impact better and/or to harmonize it with the positive. It is always a matter of optimizing the impact of the tourism, which is realized through the effective management of the impact (planning and developmental process) (Gursoy et al., 2019).

At the same time, their attitudes are important for implementing measures aimed at minimizing the impact of how tourism contributes to global warming through greenhouse gas emissions, especially hotel accommodation and lodging, as well as transportation (Gössling et al., 2012).

If we desire to make significant changes to ensure sustainable development, understanding managers' attitudes and beliefs is important in order to understand the risks and opportunities for changing the 'business as usual' practice which has become unsustainable (Becken \& Hay, 2007). Considering the sociodemographic characteristics of the respondents 
and their correlation with the views expressed, previous studies, e.g. the results of the Eurobarometer survey, have also shown that more educated respondents feel well-informed about climate change (its causes, consequences and ways of fighting it), or more actively perceive the phenomenon of climate change as a very serious problem. They believe that the process may be halted, that alternative fuel can be used to combat it, and that climate change will have a more positive impact on the European economy. This is in contrast to respondents who spent a shorter time in education who do not think climate change is a serious problem (European Commission, 2009).

The importance of higher levels of completed education for developing environmental awareness and connecting the cognitive with the conative component has been previously shown by other researchers (Bradley et al., 1999). They found that increasing environmental knowledge in some individuals results in more positive attitudes and environmentally responsible intention of behaviour towards the environment (McMillan et al., 2004). The results of this study are in agreement with the results of a study conducted on the general population in Croatia, which showed that the level of education is a significant independent factor, as the results indicate that the lower the level of education, the lower the level of environmental concern (Landau et al., 2009).

Since both consumers and service providers need to develop pro-environmental attitudes and pro-environmental intentions of behaviour, the role of informed tourism managers as leaders of change is very important for the further development of tourism. Empirical research should identify, isolate, and create holders of positive change. The first step is learning about their attitudes and beliefs, as well as connecting the cognitive, affective, and conative intention of behaviour components, to which this research has contributed. The most important limitations of the survey are a relatively poor response rate of managers to the call for participation in the survey, and a possible selection bias, as it could be assumed that more managers who have more pro-environmental attitudes participated in the study because they value environmental issues more.

\section{Conclusion}

Managers' attitudes and beliefs are important in order to anticipate, plan and direct the use of mitigation measures and to manage the negative impacts of climate change and the tourist accommodation industry. This research showed that there are very few managers who are either personally engaged in an environmental NGO or accept environmental activism as their commitment, despite the strong link between tourism, industry and ecology. The membership of respondents in an environmental association or self-determined engagement in environmental activism was analysed and 39 (13.78\%) active members of different NGOS were observed among the respondents, compared to $244(86.22 \%)$ who did not report membership or activist engagement in any NGO or initiative. When comparing the three components that are constituents of attitudes in accordance with the theory of the threefold structure of attitudes, the managers have shown that the most powerful and positively-oriented was the intention of behaviour component, followed by the cognitive and finally the equally positively oriented conative component. It has also been confirmed that the beliefs and attitudes of managers in tourist accommodation differ based on their various sociodemographic characteristics. The results have confirmed that managers in tourist accommodation facilities have established beliefs and attitudes about the interinfluence of climate change and tourist accommodation. After scoring the stated degree of acceptance of individual claims according to the seven-point Likert scale, it showed the specific influence of various sociodemographic characteristics on all three components of attitude. The presented results have shown stronger pro-ecological attitudes and higher levels of ecological awareness concerning climate change among managers who are of the female gender, who have completed tertiary education, who have more years of work experience and who consider themselves as environmental activists. The results of this paper provide insight that may be relevant for the development of sustainable practices in the tourism sector and particularly in the hotel industry, as they contribute to understanding the attitudes of key decision makers and can provide the basis for predicting 
their intention of behaviour in relation to implementing environmental protection measures.

In future research, it is important to start from the limitations of this research in two directions: it is necessary to conduct a new study on a representative sample of managers and achieve full turnout in order to avoid the selection bias present in this research. In particular, an attempt should be made to compare the stated intentions of behaviour with the field research regarding the measures actually implemented in the accommodation facilities themselves.

\section{References}

Ajduković, M., Sladović Franz, B., \& Kamenov, Ž. (2005). Stavovi stručnjaka socijalne skrbi prema izdvajanju djece iz obitelji i udomiteljstvu. Ljetopis socijalnog rada, 12(1), $39-66$.

Ajzen, I. (1985). From intentions to actions: A theory of planned behavior. V J. Kuhl in J. Beckmann (Eds.), Action control (pp. 11-39). Springer.

Alessandri, G., \& Vecchione, M. (2015). On the factor structure of the Rosenberg (1965) General Self Esteem Scale. American Psychological Association, 27(2), 621-635.

Amelung, B., Nicholls, S., \& Viner, D. (2007). Implications of global climate change for tourism flows and seasonality. Journal of Travel Research, 45(3), 285-296.

Ančić, B., Puđak, J., \& Domazet, M. (2016). Vidimo li klimatske promjene u Hrvatskoj? Istraživanje stavova o nekim od aspekata klimatskih promjena u hrvatskom društvu. Hrvatski meteorološki časopis, 51, 27-45.

Becken, S. (2019). Decarbonising tourism: Mission impossible? Tourism Recreation Research, 44(4), 419-433.

Becken, S., \& Hay, J. E. (2007). Tourism and climate change: Risks and opportunities. Channel View Publications.

Becken, S., Whittlesea, E., Loehr, J., \& Scott, D. (2020). Tourism and climate change: Evaluating the extent of policy integration. Journal of Sustainable Tourism, 28(10), 1-22.

Bohdanowicz, P. (2005). European hoteliers' environmental attitudes: Greening the business. Cornell Hotel and Restaurant Administration Quarterly, 46(2), 188-204.

Bohdanowicz, P. (2006). Environmental awareness and initiatives in the Swedish and Polish hotel industries: Survey results. International Journal of Hospitality Management, 25(4), 662-682.

Bradley, J., Campbell, T., Waliczek, M., \& Zajicek, J. M. (1999). Relationship between environmental knowledge and environmental attitude of high school students. The Journal of Environmental Education, 30(3), 17-21.
Buckley, R. (2011). Tourism and environment. Annual Review of Environmental and Resources, 36, 397-416.

Cannonier, C., \& Burke, M. G. (2018). The economic growth impact of tourism in small island developing states: Evidence from the Caribbean. Tourism Economics, 25(1), 85108.

Dawson, J., \& Scott, D. (2007). Climate change vulnerability of the Vermont ski torism industry (USA). Annals of Leisure Research, 10(3-4), 550-572.

Dogru, T., \& Bulut, U. (2018). Is tourism an engine for economic recovery? Theory and empirical evidence. Tourism Management, 67, 425-434.

Dogru, T., Marchio E. A., Bulut, U., \& Suess, C. (2019). Climate change: Vulnerability and resilience of tourism and the entire economy. Tourism Management, 72, 292-305.

Dube, K., \& Nhamo, G. (2020). Tourist perceptions and attitudes regarding the impacts of climate change on Victoria Falls. Bulletin of Geography, Socio-Economic Series, $47(47), 27-44$.

European Travel Commission. (2018). Tourism and climate change mitigation: Embracing the Paris agreement - pathways to decarbonisation. Brussels.

European Commission. (2009). Europeans' attitudes towards climate change: Report (Special Eurobarometer 300).

European Commission. (2017). Climate change: Report (Special Eurobarometer 459).

Fazio, H. F. (1993). Variability in the likelihood of automatic attitude activation: Data reanalysis and commentary on Bargh, Chaiken, Govender, and Pratto. Journal of Personality and Social Psychology, 64(5), 753-758.

Galeotti, M., \& Roson, R. (2012). Economic impacts of climate change in Italy and the Mediterranean: Updating the evidence. Journal of Sustainable Development, 5(5), 27-41.

Garay, L., Font, X., \& Corrons, A. (2018). Sustainability Oriented innovation in tourism: An analysis based on the decomposed theory of planned behaviour. Journal of Travel Research, 58(4), 622-636.

Gössling, S., \& Scott, D. (2018). The decarbonisation impasse: Global tourism leaders' views on climate change mitigation. Journal of Sustainable Tourism, 26(2), 1-16.

Gössling, S., Scott, D., \& Hall, M. (2013). Challenges of tourism in a low carbon economy. WIRES Climate Change, 4(6), 525-538.

Gössling, S., Scott, D., Hall, C. M., Ceron, J. P., \& Dubois, G. (2012). Consumer behaviour and demand response of tourists to climate change. Annals of Tourism Research, 39(1), 36-58.

Gursoy, D., Ouyang, Z., Nunkoo, R., \& Wei, W. (2019). 
Residents' impact perceptions of and attitudes towards tourism development: A meta-analysis. Journal of Hospitality Marketing \& Management, 28(3), 306-333.

Hall, C. M. (2019). Constructing sustainable tourism development: The 2030 Agenda and the managerial ecology of sustainable tourism. Journal of Sustainable Tourism, 27(7), 1044-1060.

Hall, C. M., Daval, N., Majstorović, D., Mills, H., PaulAndrews, L., Wallace, C., \& Truong, V. D. (2016). Accommodation consumers and providers attitudes, behaviours and practices for sustainability: A systematic review. Sustainability, 8(625), 1-30.

Hambira, W. L., \& Saarinen, J. (2015). Policy-makers' perceptions of the tourism-climate change nexus: Policy needs and constraints in Botswana. Development Southern Africa, 32(3), 350-362.

Hamilton, J. M., \& Tol, R. S. J. (2007). The impact of climate change on tourism in Germany, the UK and Ireland: A simulation study. Regional Environmental Change, 7(3), 161-172.

Hindley, A., \& Font, X. (2017). Etics and influence sin tourist perceptions of climate change. Current Issues in Tourism, 2o(16), 1-17.

Hoogendoorn, G., Grant, B., \& Fitchett, J. (2015). Towards green guest houses in South Africa: The case of Gauteng and KwaZulu-Natal. South African Geographical Journal, 97(2), 123-138.

IP CC. (2014). Climate change 2014: Synthesis report; Contribution of Working Groups I, II and III to the Fifth Assessment Report of the Intergovernmental Panel on Climate Change. https://www.ipcc.ch/site/assets/uploads/ 2018/o2/SYR_AR5_FINAL_full.pdf

Jentos, A. C., Malone, E., Mastrangelo, E., Hardee, K., \& Bremond, A. (2012). Linking climate change and development goals: Framing, integrating and measuring. Climate and Development, 4(2), 141-156.

Joop, R., De Lacy, T., Mair, J., \& Fluker, M. (2013). Using a regional tourism adaptation framework to determine climate change adaptation option for Victoria's surf coast. Asia Pacific Journal of Tourism Research, 18(1-2), 144164.

Jopp, R., Mair, J., Delacy, T., \& Fluker, M. (2015). Climate change adaptation: Destination management and the green tourist. Tourism Planning \& Development, 12(3), 300-320.

Kocak, E., Ulucak, R., \& Şentürk Ulucak, Z. (2020). The impact of tourism developments on $\mathrm{CO}_{2}$ emissions. Tourism Management Perspectives, 33, 100611. https://doi .org/10.1016/j.tmp.2019.100611
Kozak, N., Uysal, M., \& Birkan, I. (2008). An analysis of cities based on tourism supply and climatic conditions in Turkey. Tourism Geographic, 10(1), 81-97.

Landau, S., Legro, S., \& Vlašić, S. (2009). A climate for change: Climate change and its impacts on society and economy in Croatia. UNDP Croatia.

Legrand, W., Kirsche, C., Sloan, P., \& Simons-Kaufmann, C. (2012). Making 202020 happen: Is the hospitality industry mitigating its environmental impacts? The barriers and motivators that German hoteliers have to invest in sustainable management strategies and technologies and their perceptions of online self help toolkits. WIT Transactions on Ecology and the Environment, 161, 115-126.

Leiserowitz, A., Edward, W., Maibach, E. W., \& Roser-Renouf, C. (2018) Climate change in the American mind: March 2018 Yale project on climate change communication. George Mason University Center for Climate Change Communication.

Mahadew, R., \& Appadoo, K. A. (2019). Tourism and climate change in Mauritius. Tourism Review, 74(2), 204-215.

McMillan, E. E., Wright, T., \& Beazley, K. (2004). Impact of a university-level environmental studies class on students' values. The Journal of Environmental Education, 35(3), 19-27.

Michailidou, A. V., Vlachokostas, C., \& Moussiopoulos, N. (2016). Interactions between climate change and the tourism sector: Multiple-criteria decision analysis to assess mitigation and adaptation options in tourism areas. Tourism Managemet, 55, 1-12.

Müller, H., \& Weber, F. (2008). Climate change and tourism - Scenario analysis for the Bernese Oberland in 2030. Tourism Review, 63(3), 57-71.

Myers, D., \& Twenge. J. (2016). Loose-leaf for social psychology (12th ed.). McGraw-Hill Education.

Perić, J., \& Šverko Grdić, Z. (2017). Klimatske promjene i turizam. University of Rijeka.

Racz, A. (2019). Climate changes as determinants in shaping tourism supply: Attitudes of management; Doctoral dissertation summary. Tourism and Hospitality Management, 25(2), 439-444.

Rosselló-Nadal, J. (2014). How to evaluate the effects of climate change on tourism. Tourism Management, 42(c), 334-340.

Rutty, M., Scott, D., Johnson, P., Pons, M., Steiger, R., \& Vilella, M. (2017). Using ski industry response to climatic variability to assess climate change risk: An analogue study in eastern Canada. Tourism Management, $58,196-204$.

Saarinen, J., \& Rogersion, C. M. (2014). Tourism and the mil- 
lennium development goals: Perspectives beyond 2015 . Tourism Geographies, 16(1), 23-30.

Scheyvens, R., \& Hughes, E. (2018). Can tourism help to 'end poverty in all its forms everywhere'? The challenge of tourism addressing SDG1. Journal of Sustainable Tourism, 27(7), 1061-1079.

Schliephack, J., \& Dickinson, J. E. (2017). Tourists' representations of coastal managed realignment as a climate change adaptation strategy. Tourism Management, 59, 182-192.

Scott, D., \& Becken, S. (2010). Adapting to climate change and climate policy: Progress, problems and potentials. Journal of Sustainable Tourism, 18(3), 283-295.

Scott, D., \& Brenda, J. (2007). A regional comparison of the implications of climate change for the golf industry in Canada. The Canadian Geographer, 51(2), 219-232.

Scott, D., \& Lemieux, C. (2010). Weather and climate information for tourism. Procedia Environmental Science, 1(1), 146-183.

Scott, D., Hall, S. M., \& Gössling, S. (2019). Global tourism vulnerability to climate change. Annals of Tourism Research, 77, 49-61.

Sinatra, G. M., Kardash, C. M., Taasoobshirazi, G., \& Lonbardi, D. (2012). Promoting attitude change and expressed willingness to take action toward climate change in college students. Instructional Science, 4o(1), 1-17.

Stern, P. C., \& Oskamp, S. (1987). Managing scarce environmental resources. In D. Stokols \& I. Altman (Eds.), Handbook of environmental psychology (pp. 1044-1088). Wiley.

Torres-Bagur, M., Palom, A. R., \& Vila-Subirós, J. (2019). Perceptions of climate change and water availability in the Mediterranean tourist sector. International Journal of Climate Change Strategies and Management, 11(4), 552569.

Trawoger, L. (2014). Convinced, ambivalent of annoyed: Tyrolean ski tourism stakeholders and their perceptions of climate change. Tourism Management, 40(1), 338-351.

Wajahat, A., Farah, S., Tafazal, K., Hui, L., Muhammad, Z., \& Kazi Sohag. (2020). A cointegration analysis of structural change, international tourism and energy consumption on $\mathrm{CO}_{2}$ emission in Pakistan. Current Issues in Tourism, $23,1-15$.

Wong, R., Jiang, M., Klint, L., DeLacy, T., Harrison, D., \& Dominey-Howes, D. (2013). Policy environment for the tourism Sector's adaptation to climate change in the South Pacific - The case of Samoa. Asia Pacific Journal of Tourism Research, 18(1-2), 52-71.

Wyss, R., \& Abegg, B. (2014). Percpetions of climate change in a tourism governance context. Tourism Management Perspectives, 11(c), 69-76.

Yi-Ping, S., Hall, M., \& Ozanne L. (2013). Hospitality industry responses to climate change: A benchmark study of Taiwanese tourist hotels. Asia Pacific Journal of Tourism Research, 18(1-2), 92-107.

\section{Appendix: Exploring Attitudes and Beliefs of Leading Managers in Tourism about the Reciprocal Impact of Climate Change and Tourism and the Effect of Climate Change on Shaping the Tourism Offer}

\section{Greetings,}

Your participation will enable insight into the attitudes and beliefs of leading managers in tourism, who are exceptionally important for implementing measures for adapting the tourism sector to climate change. This research is conducted for the purpose of preparing a doctoral thesis within the scope of the Management of Sustainable Development at the Faculty of Tourism and Hospitality Management in Opatija. As the research is oriented towards manager attitudes, we kindly ask that the questionnaire be filled by a person at a manager position in your company and/or object (owner or member of the executive or oversight board, director, head of the department for environmental protection or department of quality or similar). We guarantee that the results will only be used for academic purposes. Participation in the research is anonymous and voluntary, and the results presented will not be able to be traced to any person or company that fills in the questionnaire. Filling in the questionnaire takes about 15 minutes. Taking into consideration how precious time can be, we thank you for participating and for your contribution. Thank you for your cooperation.

Below are multiple statements concerning climate change, global warning, and the relationship between tourism and climate change. Please express the degree to which you agree or disagree with each given statement on a scale from 1 to 7, where 1 means 'I completely disagree', 4 means 'I neither agree nor disagree, and 7 means 'I completely agree with the statement. Please mark only one response to each statement.

1. Climate change is a serious global issue

2. Economy and tourism can be strengthened and employment increased by fighting climate change and a more efficient use of energy

3. The impact of tourism accommodation on pollution is negligible compared to the benefit it brings to the local community

4. Climate change in the near future will have a significant effect on shaping and developing the tourism offer in Croatia 
5. Global warming is predominantly caused by human activity

6. Global warming is caused by activities related to natural causes and climate variation regardless of human activity

7. The total impact of tourism on global warming and climate change is significantly lower than the impact from other economic activities

8. Climate change and global warming will endanger future generations

9. Global warming is not actually happening at all

10. The hotel and tourism industries are big spenders when it comes to energy and other resources

11. The tourism industry depends on a preserved environment as a resource, while, paradoxically, it negatively affects the environment at the same time

12. Environmental protection, in the sense of reducing global warming, is paramount for the sustainable development of tourism

13. It is important that the Government sets national goals for increasing the use of renewable energy such as wind or solar energy

14. Implementing the principles of sustainable development in business practices is an important source of competitive advantage

15. Scientists do not have a clear answer regarding what causes global warming

16. It is important that the Government continuously secures resources on the national level to support programmes for raising energy efficiency

17. Climate change is already significantly defining and changing the development of tourism offers worldwide

18. Climate change could endanger myself personally or my family

19. Climate change causes insecurity regarding successful business in tourism

20. An individual is powerless and helpless in the battle against climate change

21. Pollution is an unavoidable consequence of development

22. Even if climate change is happening, changes in the environment, such as a rise in average temperature, are so slow that there is no reason to be concerned

23. Over the last six months, I personally supported or participated in activities focused on mitigating climate change

24. When making a choice for purchasing a new vehicle, low fuel consumption and ecological parameters are more important to me than the vehicle's price
25. When building a new object or refurbishing an existing object, it is important for me to be guided by the concept of low energy consumption, regardless of higher initial investments

26. When choosing an energy supplier, if I had the choice, I would choose the supplier providing a higher percentage of power from renewable sources, regardless of higher prices

27. I try to reduce packaging waste by buying products with recyclable packaging

28. I try to buy local food products from local producers, even though the market offers cheaper products from other producers or imported products

29. When buying a new electronic or household appliance, I choose primarily based on energy efficiency and energy class

30. Every day I try to reduce water and energy consumption

On a scale from 1 to 7 , please mark to which degree thinking about climate change and global warming causes you to feel the stated emotions, where a mark of 1 means 'does not cause the stated emotion at all,' while a mark of 7 means 'very strongly causes the stated emotion.'
31. Fear
32. Anger
33. Helplessness
34. Indifference
35. Anxiety
36. Excitement

Here are some statements regarding global issues around the world, including climate change. Please answer the following questions by selecting one or more of the answers provided.

37. Which of the following problems do you consider to be the currently most serious issue that the world is facing? (Note: Please select only one answer.)
a) Climate change
b) International terrorism
c) Poverty, famine and lack of drinkable water
d) Spread of infectious diseases
e) Economic crisis
f) Proliferation of nuclear weapons
g) Armed conflicts and the refugee crisis
h) Global increase of population
i) None of the above
j) I cannot answer the question

38. What else, in addition to your answer to question 37 , do you consider to be serious issues that the world is 
currently facing? (Note: Please select no more than three answers from options 1-9, or one answer from options 10 or 11.)
a) Climate change
b) International terrorism
c) Poverty, famine and lack of drinkable water
d) Spread of infectious diseases
e) Economic crisis
f) Proliferation of nuclear weapons
g) Armed conflicts and the refugee crisis
h) Global increase of population
i) Recession and economic crisis
j) None of the above
k) I cannot answer the question

39. According to your opinion, who in the $\mathrm{EU}$ is the most responsible for the struggle against climate change? (Note: Please select only one answer.)
a) National governments
b) European Union
c) Regional and local governments
d) Individual people
e) Environmental groups and movements
f) Global corporations
g) Someone or something else
h) All of the above
i) None of the above
j) I cannot answer the question

40. The following list contains procedures and activities that can be done to reduce energy consumption and affect climate change. Please select all options that ... what?

a) Primary waste selection and separation for collection

b) Automatic air conditioning control when opening windows in accommodation units

c) Limiting the temperature in accommodation units during the day and at night

d) Reducing external ambient lighting late at night

e) Reducing energy consumption (sauna temperature, jacuzzi, air temperature and similar) in wellness and spa zones at times when there are no guests

f) Driving vehicles that use renewable energy sources for transporting guests and goods within the accommodation complex g) Availability of bicycles and similar means of transportation to reduce the use of cars in place of residence

h) Limiting the use of chemical products when maintaining property

i) Implementing a programme for reusing bed linen and towels in agreement with guests

j) Installing reduction valves, sinks and showers that save time and water

k) Securing a part of the energy requirements from own sources (solar panels and similar)

1) Encouraging guests to reduce waste generation concerning unused food and leftovers from meals

m) Recycling and reusing waste whenever possible

n) Purchasing food products from local suppliers whenever possible

o) Donating scrapped equipment, technology, furniture, consumable supplies and similar to the local community

p) Redistributing excess food to employees or the local community

q) Designing leaflets to remind guests to use resources (energy, food, water,...) responsibly

Please describe the characteristics of the tourism object in which you hold the manager position

- Location of object

1. Adriatic Croatia

2. Continental Croatia

- Type of business

1. Seasonal business

2. Year-round business

- Size of object

1. Small ( $\leq 50$ rooms/units)

2. Medium (51-100 rooms/units)

3. $\operatorname{Big}(>100$ rooms/units)

- Available pool, fitness, spa and/or wellness or similar

1. Yes

2. No

- Category

1. 2-star

2. 3-star

3. 4-star

4. 5-star

- Type of object

1. Hotel or resort hotel 
2. Holiday village

3. Camp

4. Marina

- Primary reason for guests coming to your object

1. Congress/business tourism

2. Rest and recreational tourism

3. Health and wellness tourism

4. Other

- Type of guests

1. Individual guest

2. Family guests

3. Organized groups

4. Other

- Type of ownership

1. Individual object

2. Part of a larger chain of tourism objects (part of domestic or international corporation or group)

3. Other

- Having a written Environmental Protection Policy, either as an individual document or as part of a currently valid quality assurance certificate.

1. Yes

2. No

Sociodemographic information about the participant

- Gender

1. Male

2. Female
- Education level
1. Middle
2. Higher, undergraduate
3. High
4. Postgraduate degree

- Membership in pro-environmental organization or active environmental activism

1. Yes

2. No

- Years of work experience in tourism

1. Less than 5 years

2. 5-15 years

3. More than 15 years

- Participant's level of responsibility

1. Executive or Oversight Board member/Member of object's strategic management or owner group

2. Director/Object manager/Member of object's operative management

3. Head of Quality/Head of Environmental Protection

4. Middle management

5. Other 